\title{
Observations on impact of stunting on breeding performance of farmed rohu Labeo rohita (Hamilton, 1822)
}

\author{
P. P. SURESH BABU ${ }^{1,2}$, P. SRINIVASA RAO ${ }^{1}$, J. KRISHNA PRASAD ${ }^{1}$, RUPAM SHARMA ${ }^{3}$, \\ A. M. BABITHA RANI ${ }^{3}$ AND I. F. BIJU ${ }^{4}$ \\ ${ }^{1}$ Kakinada Centre of ICAR-Central Institute of Fisheries Education, Kakinada - 533 001, Andhra Pradesh, India \\ ${ }^{2}$ Karwar Regional Station of ICAR-Central Marine Fisheries Research Institute, Baithkol, Karwar - 581302 \\ Karnataka, India \\ ${ }^{3}$ ICAR-Central Institute of Fisheries Education, Mumbai - 400 061, Maharashtra, India \\ ${ }^{4}$ ICAR-Central Institute of Brackishwater Aquaculture, Chennai - 600 028, Tamil Nadu, India \\ e-mail:sbabu78@yahoo.com
}

\begin{abstract}
Breeding performance of stunted rohu Labeo rohita (Hamilton, 1822) was compared with normally reared rohu. Randomly selected stunted and normal fishes were tagged and reared together in a single earthen pond for broodstock development. Both groups exhibited growth enhancement during the broodstock development period, though normal fishes were found larger in size than the stunted fishes, after the rearing period. Gonadosomatic Index (GSI) of female fishes indicated a similar trend of ovary growth in both the groups. Breeding performances of the broodstocks were evaluated by induced breeding trials. Parameters such as absolute fecundity, relative fecundity, number of spawns produced and hatching percentage were significantly higher $(\mathrm{p}<0.05)$ (almost double) in normal fishes than the stunted fishes. The present results indicate that the stunting process (6 months) is having detrimental effect on the breeding performance of rohu and thus stunted fishes are not ideal for broodstock development.
\end{abstract}

Keywords: Fecundity, Gonadosomatic index, Rohu, Stunted fish

In nature, stunted fish population includes individuals that grow slowly and mature early, in which growth is restricted by density-dependent mechanisms and the retarded growth is not determined genetically (Chizinski et al., 2010). Ali et al. (2003) described compensatory, or catch-up growth as, animals experiencing a period of growth depression may achieve the same size-at-age as and when it receives favourable environmental conditions. Application of stunting followed by growth compensation has been exploited for enhancing production in several species of farmed fish. Compensatory growth pattern has been evaluated in several commercially important cultured fishes such as olive flounder (Cho and Cho, 2009), Nile tilapia (Bhujel et al., 2007), big head carp (Santiago et al., 2004), channel catfish (Hatch et al., 1998) and sun fish (Hayward et al., 1997) all over the globe.

Stunted carp fingerlings are used extensively for grow-out culture in many parts of the Indian subcontinent and South-east Asian countries (Nandeesha et al., 1994). One year old stunted fingerlings (stunted yearlings) are the preferred stocking material for carp culture because of their ability to compensate growth and better survival (Jena, 2006; Charan et al., 2012). Thus they fetch more price for the seed growers and traders (Radheysham and
Saha, 2009). Stunted fishes are produced by stocking the fingerlings in nursery ponds at higher stocking rates with minimum feed for their survival (Radheysham and Saha, 2009). Gonadal development in stunted fishes during the culture is reported to affect the somatic yield (Charan et al., 2012).

There is only limited systematic experimental studies on the impact of stunting on reproduction (Ali et al., 2003). Studies describing the effect of various stunting processes on the reproductive performance has been reported in tilapia Oreochromis niloticus (Bhujel et al., 2007) and big head carp Aristichthys nobilis (Santiago et al., 2004). Such studies are necessary in the most preferred Indian major carp, rohu Labeo rohita (Hamilton, 1822), since major portion of the broodstock for commercial seed production of this species is from commercial farms.

Stunted and normal fingerlings of rohu were obtained from the freshwater fish farm of ICAR-Central Institute of Fisheries Education (ICAR-CIFE), Kakinada Centre, Kakinada, Andhra Pradesh, India. For this, fingerlings produced from a single mother stock were used. Stunted fingerlings were produced by rearing frys of rohu at 10 fry $\mathrm{m}^{-2}$ in a $200 \mathrm{~m}^{2}$ earthen pond (1.5 m water depth) 
for six months (February to July 2013) with restricted feeding ( $3 \%$ of the body weight) with a commercial pellet feed (UNO feeds Pvt. Ltd., Bhimavaram, Andhra Pradesh, India; crude protein $28-30 \%$; fat $4-5 \%$; carbohydrate $15-20 \%$; ash $<5 \%$; Fibre $<5 \%$ and moisture $<10 \%$ ). Normal fingerlings were produced by stocking frys from the same group at a density of $1 \mathrm{fish} \mathrm{m}^{-2}$ in $200 \mathrm{~m}^{2}$ earthen ponds for six months by feeding same pellet feed at $10 \%$ of their body weight. After six months rearing, the normal and stunted fingerlings were reared further for six months (August 2013 to January 2014) separately in $200 \mathrm{~m}^{2}$ earthen ponds ( $1.5 \mathrm{~m}$ water depth) in three replicates at a stocking rate of 1 fish $\mathrm{m}^{-2}$ for evaluating the post-stunting growth (results not shown). During this period, the fishes were fed up to satiation with the same pellet feed.

After six months post-stunting (August 2013 to January 2014), 50 fishes each from the stunted and normal groups were randomly selected and tagged with PIT tags and stocked in a single pond $\left(200 \mathrm{~m}^{2}\right)$ and reared from February to June 2014 providing same pellet feed to develop broodstocks for comparing the reproductive performance. During the broodstock development, 30 fishes each were sampled from normal and stunted group for growth measurements. Total length of the fish from tip of snout to tip of caudal fin was measured using a wooden scale with an accuracy of $0.1 \mathrm{~cm}$. Total weight of fish was measured using a pan balance with an accuracy of $2 \mathrm{~g}$.

Specific growth rate (SGR) was calculated according to the following formula:

$$
\operatorname{SGR}(\%)=\frac{\ln (\text { Final weight })-\ln (\text { Initial weight })}{\text { Experimental periods in days }} \times 100
$$

where 'In' is the natural logarithmic value

Fulton's condition factor $(\mathrm{K})$ was calculated using the formula:

$$
\mathrm{K}=\frac{\mathrm{W} \times 100}{\mathrm{~L}^{3}}
$$

where, $\mathrm{W}=$ Weight of fish $(\mathrm{g}), \mathrm{L}=$ Length of fish $(\mathrm{cm})$.

Gonadosomatic index (GSI) of the stunted fingerlings and normal rohu were calculated during the pre-breeding (April 2014), mid-breeding (June 2014) and before the breeding experiment (July 2014). Sex differentiation of the fish was done according to secondary sexual characters such as swollen belly and smoothness of the pectoral fins in females (Jhingran and Pullin, 1985). For GSI calculation ovaries were collected from 3 fishes each from normal and stunted groups. Total weight and gonadal weight of individuals were noted to calculate the GSI. Total weight of the fish was measured using a top loading pan balance with an accuracy of $2 \mathrm{~g}$ and the gonadal weight was measured using an electronic balance with an accuracy of $0.001 \mathrm{~g}$. GSI was calculated using the formula:

$$
\text { GSI }=\frac{\text { Total weight of ovary }}{\text { Total weight of fish }} \times 100
$$

Water quality parameters such as dissolved oxygen, $\mathrm{pH}$, temperature, total alkalinity and total $\mathrm{CO}_{2}$ were monitored once in 15 days during the broodstock rearing period as per the standard procedures (APHA, 1988).

Four replicates of breeding pairs (males and females in 2:1 ratio) of stunted and normal fishes were maintained separately in hapas for breeding trials. The fishes were administered with single dose of ovatide (Hemmo Pharmaceuticals Pvt. Ltd., India) for males@ $0.3 \mathrm{ml} \mathrm{kg}^{-1}$ and females@0.5 ml kg-1.After injection, the fishes were maintained in separate hapas in a common water canal till spawning ( 8 to $10 \mathrm{~h}$ ). The spawned eggs were counted using a measuring cylinder and the eggs were incubated in portable Chinese hatcheries having 3001 capacity. Each hatchery was provided with eggs@2500 eggs per litre. After $72 \mathrm{~h}$, hatchlings were counted and shifted to a nursery tank.

Statistical analysis for the present work was done using SPSS version 20.0. Student's t test was performed for comparing means between different groups. All the data presented in the text, figures and tables are expressed as mean \pm standard error except for water quality parameters which is given as ranges and statistical significance for the test was set at $\mathrm{p}<0.05$.

The broodstock from stunted and normal fishes were tagged and maintained in a single pond to ensure that uniform conditions were provided for maturation of the fishes. Das et al. (2016) also stocked pre-stunted rohu fingerlings from various treatments together in a single pond in order to provide similar environmental conditions for the fishes for growth studies. Since rohu mature in the second year of its growth (Jhingran and Pullin, 1985), further rearing was needed after stunting. Range of water quality parameters such as water temperature, $\mathrm{pH}$, dissolved oxygen, dissolved $\mathrm{CO}_{2}$ and total alkalinity of the broodstock pond is given in Table 1 . Water quality parameters of the pond was in conducive range for the growth of carp broodstock (Nandi et al., 2007).

Weight gain $(\mathrm{g})$ in stunted and normal fishes during broodstock development is given in Fig. 1. During the breeding season, both stunted and normal fishes increased in weight but normal fishes $(0.933 \pm 0.12 \mathrm{~kg})$ were larger than the stunted fishes $(0.74 \pm 0.3 \mathrm{~kg})$. Specific growth rate per day $(\%)$ of stunted $(0.42)$ fishes were higher than the normal (0.21) fishes. The stunted fishes could attain only partial compensation in growth during the post-stunting 
Table 1. Range of water quality parameters recorded in the broodstock pond

\begin{tabular}{ll}
\hline Parameter & Range \\
\hline Water temperature & $26-28^{\circ} \mathrm{C}$ \\
$\mathrm{pH}$ & $8.2-8.4$ \\
Free $\mathrm{CO}_{2}$ & $3.5-5.7 \mathrm{mg} \mathrm{l}^{-1}$ \\
Dissolved oxygen & $6-7 \mathrm{mg} \mathrm{l}^{-1}$ \\
Total alkalinity & $135-155 \mathrm{mg} \mathrm{l}^{-1}$ \\
\hline
\end{tabular}

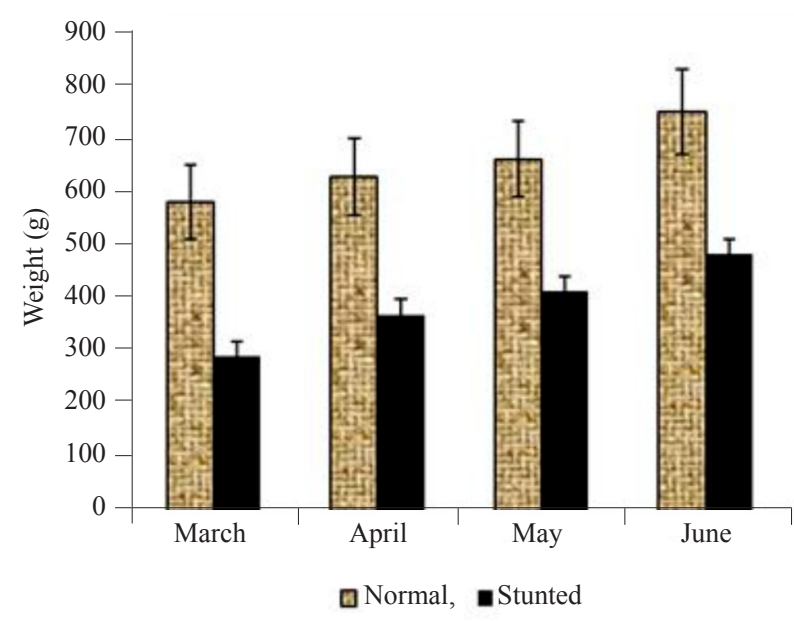

Fig. 1.Weight gain $(\mathrm{g})$ in stunted and normal fishes of rohu during broodstock development

phase, similar to that reported by Ali et al. (2003). Since the fishes were stunted for a six months period, the stunted fishes could initiate compensatory growth only late during the post-stunting growth phase (data not shown). Das et al. (2016) reported that in rohu, long term stunting process (6 months or more) may lead to delay in the initiation of compensatory growth.

Prior to the comparison of the breeding performances, gonadal development in the two groups of fishes were analysed by comparing the GSI. Fig. 2 depicts the GSI of stunted and normal fishes during breeding season. Enhancement in gonadal weight was observed in both stunted and normal fishes even though GSI was slightly higher in normal fishes. This may be due to the fact that the stunted fishes could initiate their compensatory growth at a slower pace leading to lesser feeding and thus led to comparatively slower gonadal weight enhancement.

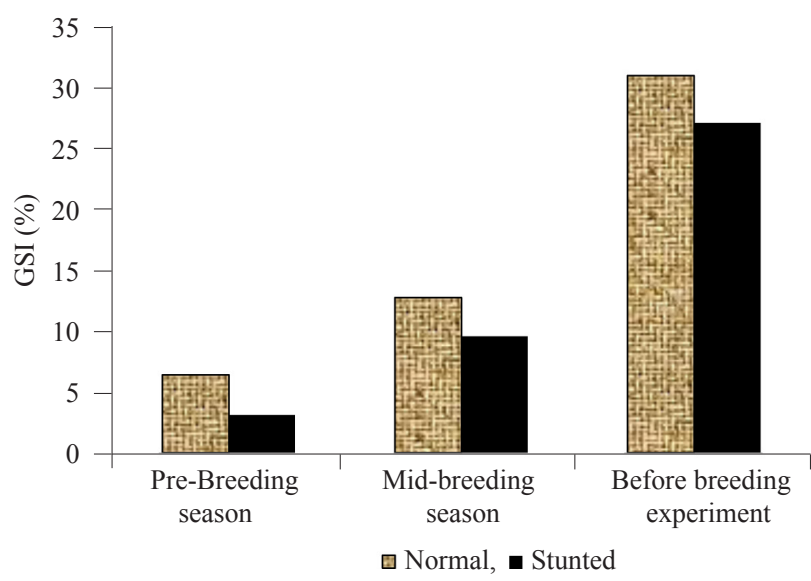

Fig. 2. Gonadosomatic index of stunted and normal fishes of rohu during breeding season

Santiago et al. (2014) also reported that prolonged stunting (more than 12 months) in bighead carp may be detrimental for broodstock development.

Details of the brooders used for the breeding trials are given in Table 2. For reducing the impact of variation in the size of the brooders on the reproductive indices, biggest fishes from both stunted and normal groups were selected. For comparison, Fulton's condition factor (k) was evaluated for the female brooders. Fulton's condition factor gives an estimate of the wellbeing of the fish species based on the isometric growth pattern (Datta et al., 2013) and is reported to have influence on the growth, survival and reproduction of the species (Hossain et al., 2006). Hossain et al. (2006) reported that ' $\mathrm{k}$ ' is having a direct relation with the monthly changes in GSI in Asian striped catfish. In the present study, $\mathrm{k}$ was found higher than one in both stunted and normal groups indicating that both groups were in good condition.

Details of breeding performance of stunted and normal fishes are given in Table 3. For evaluating the breeding performance, parameters such as absolute fecundity, relative fecundity, total number of spawns produced and the number of spawns produced per $\mathrm{kg}$ of female were considered. All the fishes in the breeding experiment responded well to the inducing agent, ovatide and released eggs. But the reproductive indices such as absolute fecundity, relative fecundity, number of spawns

Table 2. Details of brooders used for the breeding trials

\begin{tabular}{lll}
\hline Parameter & Normal group & Stunted group \\
\hline Average length of female $(\mathrm{cm})$ & $35.66 \pm 2.84$ & $32.66 \pm 1.76$ \\
Average weight of female $(\mathrm{kg})$ & $0.933 \pm 0.12$ & $0.74 \pm 0.3$ \\
Condition factor $(\mathrm{k})$ for female & 2.09 & 1.52 \\
Average weight of males used for breeding (kg) & $0.722 \pm 0.04$ & $0.629 \pm 0.01$ \\
Weight of ovary (Calculated from spawning weight loss) & $283.33 \pm 16.66$ & $198 \pm 8.2$ \\
\hline
\end{tabular}


Table 3. Comparison of reproductive indices of normal and stunted fingerlings of $L$. rohita

\begin{tabular}{|c|c|c|}
\hline Parameter & Normal group & Stunted group \\
\hline$\overline{T o t a l}$ number of eggs released (Absolute fecundity in million) ${ }^{\wedge}$ & $0.383 \pm 0.04^{\mathrm{a}}$ & $0.19 \pm 0.017^{\mathrm{b}}$ \\
\hline Egg per gram fish (relative fecundity) ${ }^{*}$ & $4.14 \pm 0.25$ & $2.55 \pm 0.12$ \\
\hline Number of hatchlings obtained (in million) ${ }^{\wedge}$ & $0.263 \pm 0.013^{\mathrm{a}}$ & $0.095 \pm 0.02^{\mathrm{b}}$ \\
\hline Hatchlings per $g$ fish (Relative hatchling production) ${ }^{*}$ & $2.9 \pm 0.33$ & $1.26 \pm 0.24$ \\
\hline Hatching $\%^{*}$ & 70.46 & 48.75 \\
\hline
\end{tabular}

$\wedge$ Values with same superscript as a pair in a row differs significantly. ${ }^{*}$ Ratios and percentages were not subjected to statistical analysis

produced and hatching percentage were significantly higher $(\mathrm{p}<0.05)$ (almost double) in normal fishes than the stunted fishes. The most possible explanation for this condition is that, increase in feeding rate increased the size (weight) of the fish and those bigger fish might have produced more eggs per spawning in normal group. Reduction in breeding performance has already been reported at lower feeding rates in Nile tilapia (Macintosh and Little, 1995; Bhujel et al., 2007). Fecundity and size of the brooders varied considerably among breeding trials of rohu as reported by Mishra et al. (2001) and Das et al. (2004), but hatching percentage of eggs produced by the stunted fishes in the present work was noticeably low.

The present results indicate that stunting process is having impact on the breeding performance of rohu especially on the GSI, fecundity and hatching. Results of the present study indicate that stunted fishes should be avoided while selecting brooders for future breeding programmes. In Indian sub-continent, majority of the farmers rely on brooders collected from commercial farms for large scale seed production where stunted fishes are used for stocking. This may in turn affect the seed production of the species in the coming future.

\section{Acknowledgments}

The authors sincerely acknowledge the research guidance and financial support extended by the Director, ICAR-CIFE, Mumbai, for executing the present work.

\section{References}

Ali, M., Nicieza, A. and Wootton, R. J. 2003. Compensatory growth in fishes: A response to growth depression. Fish Fish., 4: 147-190. https://doi.org/10.1046/j.14672979.2003.00120.x.

APHA 1988. Standard methods for the examination of water and wastewater, $20^{\text {th }}$ edn. American Public Health Association, American Water Works Association and Water Environment Federation, Washington DC, USA.

Bhujel, R. C., Little, D. C. and Hossain, A. 2007. Reproductive performance and the growth of pre-stunted and normal Nile tilapia (Oreochromis niloticus) broodfish at varying feeding rates. Aquaculture, 273: 71-79. https://doi.org/10.1016/j. aquaculture.2007.09.022.
Charan, R., Suresh Babu, P. P., Razvi, S. S. H., Venugopal and Anuraj, A. 2012. Lower size at maturation reduces somatic yield in pond reared stunted yearlings of rohu Labeo rohita (Hamilton). Indian J. Fish., 59: 171-174.

Chizinski, C. J., Pope, K. L., Wilde, G. R. and Strauss, R. E. 2010. Implications of stunting on morphology of freshwater fishes. J. Fish Biol., 76: 564-579. https://DOI: 10.1111/ j.1095- 8649.2009.02498.x.

Cho, Y. J. and Cho, S. H. 2009. Compensatory growth of olive flounder Paralichthys olivaceus, fed the extruded pellet with different feeding regimes. J. World Aquac. Soc., 40: 505-512. https://doi.org/10.1111/j.1749-7345.2009.00270.x.

Das, P. C., Mishra, S. S., Mishra, B. and Jayasankar, P. 2016. Influence of juvenile stunting on grow-out performance of rohu Labeo rohita (Hamilton, 1822). J. Appl. Ichthyol., 32: 848-858. https://DOI: 10.1111/jai.13131.

Das, S. K., 2004. Evaluation of a new spawning agent, Ovopel in induced breeding of Indian carps. Asian Fish. Sci., 17: 313-322

Datta, S. N., Kaur, V. I., Dhawan, A. and Jassal, G. 2013 Estimation of length-weight relationship and condition factor of spotted snakehead Channa punctata (Bloch) under different feeding regimes. Springer Plus, 2: 436, 1-5. https://doi:10.1186/2193-1801-2-436.

Hatch, U., Hansen, T. R., Kim, M. K. and Lovell, R. T. 1998. Economic analysis of overwinter feeding regimens for channel catfish, Ictalurus punctatus. Aquac. Econ. Manag., 2: $141-150$.

Hayward, R., Noltie, D. and Wang, N. 1997. Use of compensatory growth to double hybrid sunfish growth rates. Trans. Am. Fish. Soc., 126(2): 316-322. https://doi.org/10.1577/15488659(1997)126<0316:NUOCGT> 2.3.CO;2.

Hossain, M. Y., Ahmed, Z. F., Leunda, P. M., Jasmine, S., Oscoz, J., Miranda, R. and Ohtomi, J. 2006. Condition, length-weight and length-length relationships of the Asian striped catfish Mystus vittatus (Bloch, 1794) (Siluriformes: Bagridae) in the Mathabhanga River, south-western Bangladesh. J. Appl. Ichthyol., 22: 304-307. https://doi. org/10.1111/j.1439-0426.2006.00803.x.

Jena, J. K. 2006. Cultured aquatic species information programme: Labeo rohita. Fisheries and Aquaculture Department, Food and Agriculture Organisation of the United Nations, Rome, Italy. http://www.fao.org/fishery/ culturedspecies/Labeorohita/en. 
Jhingran, V. G. and Pullin, R. S. V. 1985. A hatchery manual for the common Chinese and Indian major carps. ICLARM Studies and Reviews, No. 11. Asian Development Bank, Manila, Philippines and International Centre for Living Aquatic Resources Management, Manila, Philippines, 191 pp.

Macintosh, D. J. and Little, D. C. 1995. Nile tilapia (Oreochromis niloticus), In: Bromage, N. R. and Roberts, R. J. (Eds.), Broodstock management and egg and larval quality, Blackwell Science Publication, University Press, Cambridge, UK, p. 277-320.

Mishra, S. S., Pradhan, P., Dutta, N. C. and Chakarabarty, S. K., 2001. Studies on the performance of 'ovatide' on breeding of Indian major carps. J. Indian Fish. Ass., 28: 125-129.

Nandeesha, M. C., Dathathri, K., Krishnamurthy, D., Vargese, T. J., Gangadhar, B. and Umesh, N. R. 1994. Effect of varied levels of protein on the growth and tissue biochemistry of stunted fingerlings of rohu Labeo rohita in the absence and presence of natural food.
In: De Silva, S. S. (Ed.), Proceedings of the fifth Asian Fish Nutrition Workshop, Special publication. Fish nutrition research in Asia. Asian Fisheries Society, Manila, Philippines, p. 93-100.

Nandi, S., Routray P., Gupta, S. D., Rath, S. C., Dasgupta, S., Meher, P. K. and Mukhopadhyay, P. K.2007. Reproductive performance of carp Catla catla (Ham.), reared on a formulated diet with PUFA supplementation. J. Appl. Ichthyol., 23: 684-691.https://doi.org/10.1111/j.1439-0426. 2007.00874.x.

Radheysham, H. K. and Saha, G. S. 2009. Role of community in production of larger and quality fingerlings. Aquac. Asia Magaz., 14(1): 16-17.

Santiago, C. B., Gonzal, A. C., Aralar, E. V. and Arcilla, R. P. 2004. Effects of stunting of juvenile bighead carp Aristichthys nobilis (Richardson) on compensatory growth and reproduction. Aquac. Res., 35(9): 836-841. https://doi. org/10.1111/j.1365-2109.2004.01074.x. 